\title{
MALIGNANT HYPERTHERMIA AND ALTHESIN
}

\author{
Natsuo Honda, Kanji Konno, Yuzo Itohda, Masataka Nishino, \\ Sachiko Matsushima, Sumitaka Haseba, Yuzuru Honda, and Yutaka Gotoh
}

Malignant hyperthermia is a pharmacogenetic syndrome induced by administration of anaesthetics and muscle relaxants. ${ }^{1-3}$ However, since the aetiology is not yet entirely understood, anaesthetists find it difficult to select proper anaesthetics for patients considered to be at risk. Therapeutic regimens have been recommended for management of this syndrome ${ }^{4-9}$ but the problem of selecting a safe anaesthetic is not yet resolved. Hall, et al. ${ }^{10}$ and Harrison ${ }^{11}$ reported studies suggesting that Althesin is an appropriate anaesthetic in this disease. Further recent reports indicate that Althesin anaesthesia is safe for patients who have survived episodes of Malignant Hyperthermia. ${ }^{12,13}$

Althesin is a rapid and short-acting steroid intravenous anaesthetic which is not vasoactive. ${ }^{14-17}$ The authors had occasion to use Althesin on patients with a history of malignant hyperthermia ${ }^{18}$ and arthrogryposis multiplex congenita, both of whom had fever associated with previous anaesthetics. ${ }^{19}$ In both cases the results were satisfactory.

\section{Case Report I}

A nine-year-old female child was admitted for a plastic operation to the hip related to a congenital atrophy of the femur. She was subjected to general anaesthesia with nitrous oxide-oxygen, halothane and succinylcholine chloride. She developed an episode of Malignant Hyperthermia, which responded satisfactorily to treatment.

Following this episode the family was investigated. Electromyography demonstrated subclinical myopathy in her father and two brothers. Her mother was normal. ${ }^{20}$

The child was re-admitted for operation. At that time pre-operative investigation elicited the following information.

Height $117.5 \mathrm{~cm}$; Weight $20 \mathrm{~kg}$; Pulse rate $90 / \mathrm{min}$; Temperature $36.7^{\circ} \mathrm{C}$; Blood Pressure 120/66 mm Hg; RBC $449 \times 10^{4}$; WBC 3900; Hb 13.6 g/ dl; Hct 40 per cent; T.P. $7.7 \mathrm{~g} / \mathrm{dl}$, SGOT 18; SGPT 11 ; Na $140 \mathrm{mMol} / \mathrm{l} ; \mathrm{K} 4.0 \mathrm{mMol} / \mathrm{l}$; C1 $105 \mathrm{mMol} / \mathrm{l}$; Ca $10.2 \mathrm{mg} / \mathrm{dl}$; P $3.5 \mathrm{mg} / \mathrm{dl}$; Creatine Phosphokinase (CPK) 11 units (normal value 0-20 units); urine protein and urine sugar negative. The electromyogram showed a myogenic pattern. Electrocardiogram and chest X-ray, no remarkable change.

\section{Anaesthesia (Figure 1)}

Pre-operative medication was diazepam $6 \mathrm{mg}$, pethidine $20 \mathrm{mg}$ and atropine

Department of Anesthesiology, Nagasaki University School of Medicine, Nagasaki, Japan.

Canad. Anaesth. Soc. J., vol. 24, no. 4, July 1977 


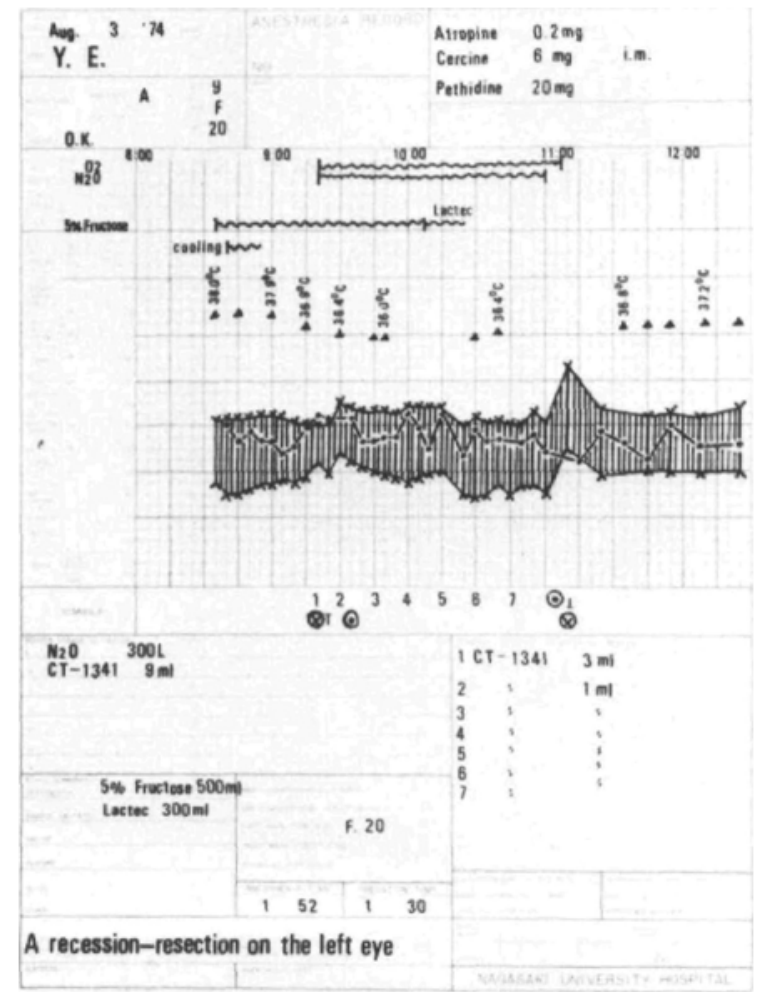

Figure 1. Record of first anaesthesia with Althesin (Case No. 1).

$0.2 \mathrm{mg}$, all intramuscular. During the hour after premedication her temperature increased from $36.7^{\circ} \mathrm{C}$ to $38.0^{\circ} \mathrm{C}$; surface cooling was instituted. Temperature started to fall within 20 minutes of commencement of cooling and 40 minutes later was $36.7^{\circ} \mathrm{C}$.

Anaesthesia for the operation of recession-resection of the extra-ocular muscles of the left eye was induced with Althesin $3 \mathrm{ml}$. Tracheal intubation was easily performed without using muscular relaxants and anaesthesia was maintained with nitrous oxide/oxygen with assisted respiration. Althesin $6 \mathrm{ml}$ was administered during the remainder of the operation. Under anaesthesia the temperature varied from $36.0^{\circ} \mathrm{C}$ to $36.2^{\circ} \mathrm{C}$ (rectal) but no muscle rigidity was observed and the anaesthesia was completed uneventfully. Recovery from anaesthesia was uneventful and five minutes after the end of the operation the patient responded to call. During the 24 hours following operation the temperature rose to $37.4^{\circ} \mathrm{C}$ maximum. $\mathrm{CPK}$ on the third post-operative day was reported as 0 units.

\section{Second Anaesthesia (Figure 2)}

Four months after the anaesthetic reported above, the patient was again anaesthetized by general anaesthesia for muscle biopsy. At this time, without premedication, atropine $0.1 \mathrm{mg}$ was administered intravenously ten minutes before induction. Temperature before anaesthesia was $37.5^{\circ} \mathrm{C}$ (axillary). CPK was 17 units 


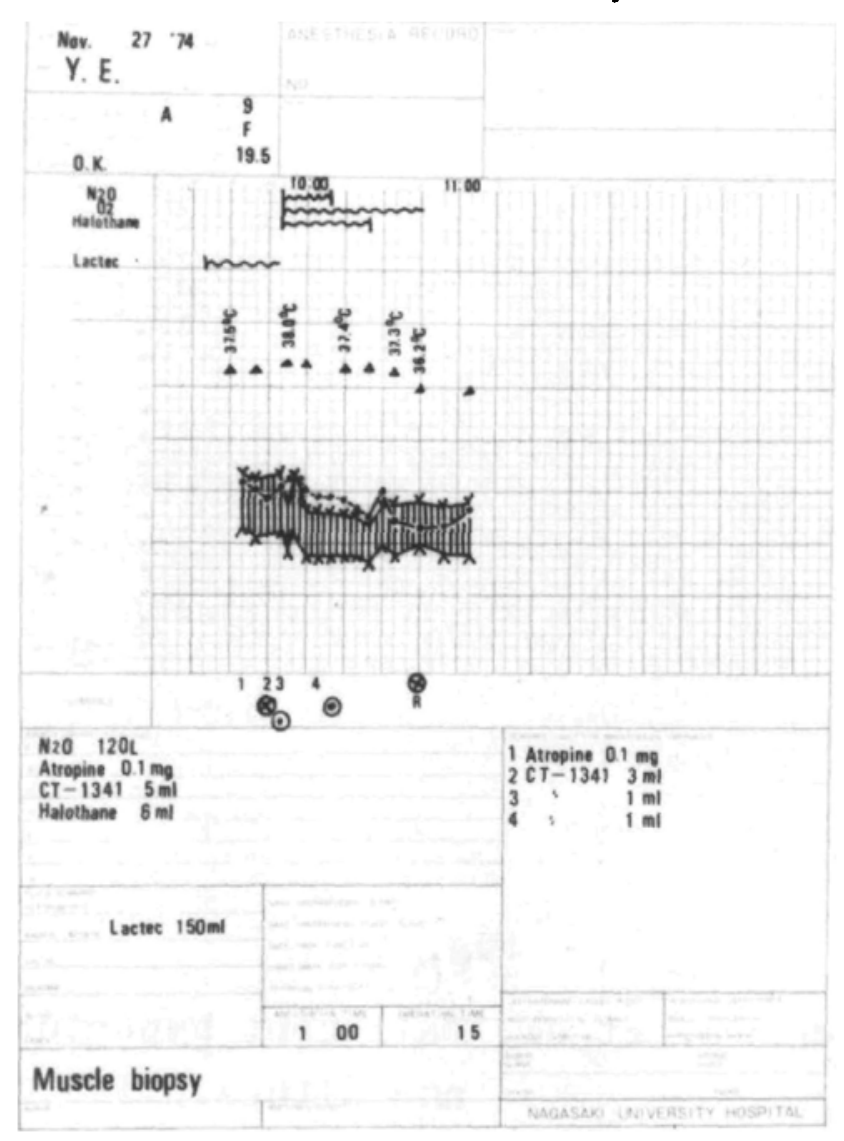

Figure 2. Record of second anaesthesia with Althesin and Halothane (Case No. I).

(normal 0-50 units). It was planned to induce anaesthesia with Althesin $3 \mathrm{ml}$ and to use nitrous oxide-oxygen and Althesin for maintenance.

Immediately after induction of anaesthesia the temperature began to fall and fluctuated between $36.2^{\circ} \mathrm{C}$ and $38.0^{\circ} \mathrm{C}$ (rectal). The operation proceeded in good order to the end but, since recovery from anaesthesia was slow, the anaesthetic machine was examined and it was determined by smell that halothane was being emitted. The concentration of halothane was 0.5 per cent and this was an accident caused by insufficient checking of the machine prior to anaesthesia. However, during the 24 hours after operation the temperature rose once only to $37.3^{\circ} \mathrm{C}$ and stabilized at about $36^{\circ} \mathrm{C}$. No special treatment was required. CPK was 21 units six hours after anaesthesia, 33 units after 12 hours, 21 units after 24 hours, 17 units after three days, and 21 units after seven days. No abnormal increase of CPK was observed.

\section{Case No. 2}

This patient was a male child two years and ten months of age who suffered from arthrogryposis multiplex congenita. 


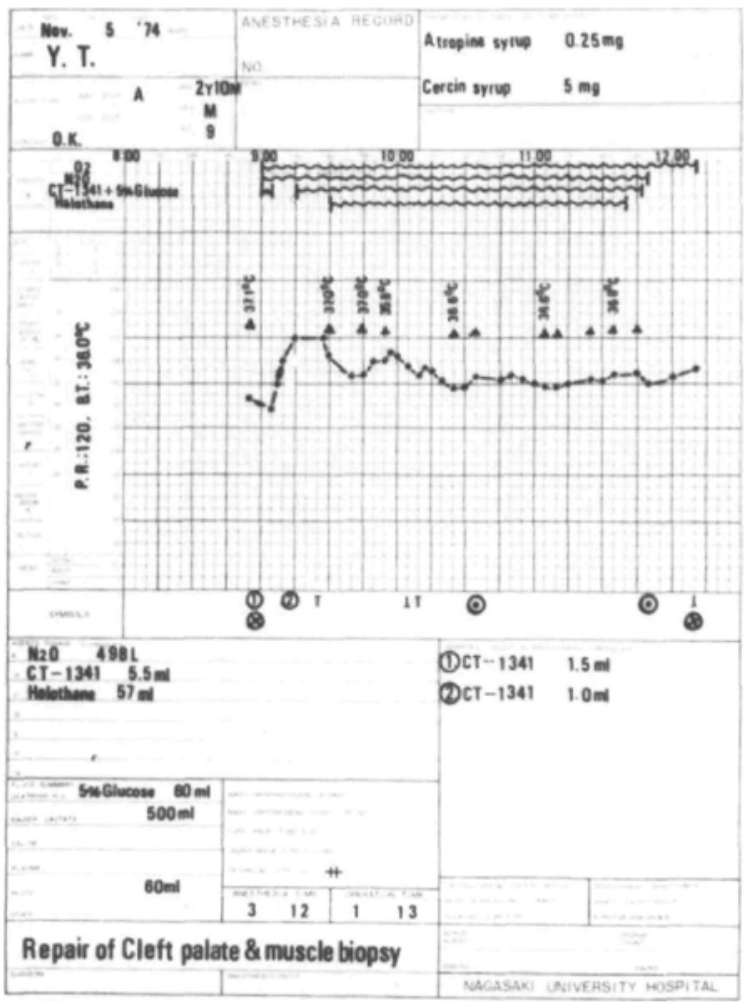

Figune 3. Record of anaesthesia with Althesin and Halothane (Case No. 2).

\section{Past history}

This patient previously had an operation for correction of club foot, which was followed subsequently by a second operation for skin grafting of wound necrosis. The first anaesthetic was managed with nitrous oxide-oxygen, halothane and succinylcholine chloride. On this occasion the temperature rose to $38.3^{\circ} \mathrm{C}$. At the second operation he was anaesthetized with nitrous oxide-oxygen, halothane and pancuronium bromide. On this occasion the temperature rose to $38.9^{\circ} \mathrm{C}$. However, in both cases cooling and other treatment worked well.

Subsequent to these episodes, electromyographic study of his parents found nothing abnormal.

\section{Present Illness}

Pre-operative investigation of this patient provided the following information.

Height $67.5 \mathrm{~cm}$; Weight $9 \mathrm{~kg}$; Pulse $100 / \mathrm{min}$; Temperature $36.4^{\circ} \mathrm{C}$; RBC 514 $\times 10^{4}$; WBC 7900; Hb $9.1 \mathrm{~g} / \mathrm{dl}$; Hot 30 per cent; T.P. $7.0 \mathrm{~g} / \mathrm{dl}$; SGOT 23; SGPT 8; Na $140 \mathrm{mMol} / 1$; K $4.2 \mathrm{mMol} / 1$; Cl $109 \mathrm{mMol} / 1$; CPK 23 units (normal value 0-130 units); EMG myogenic pattern; EKG and chest $\mathrm{X}$-ray no remarkable change.

\section{Anaesthesia (Figure 3)}

This patient was anaesthetized for repair of cleft palate and a muscle biopsy. 
The pre-operative oral medication consisted of diazepam syrup $5 \mathrm{mg}$ and atropine syrup $0.25 \mathrm{mg}$. Immediately before induction of anaesthesia CPK was 17 units and temperature $37.1^{\circ} \mathrm{C}$. Induction was Althesin $1.5 \mathrm{ml}$. Insertion of the tracheal tube without use of muscle relaxant failed but was successful after administration of additional Althesin $1 \mathrm{ml}$. Anaesthesia was maintained with nitrous oxide-oxygen and halothane 1 to 1.5 per cent and Althesin was given by intravenous drip. No muscle relaxant was used. Althesin was given by micro-drip technique as a mixture of Althesin $2.5 \mathrm{ml}$ with $60 \mathrm{ml}$ of 5 per cent glucose solution. In the initial stages of the operation the temperature gradually fell and during anaesthesia remained between $36.6^{\circ}$ and $37.0^{\circ} \mathrm{C}$ (rectal). There was no evidence of muscle rigor and no cooling was required. Recovery from anaesthesia was uneventful. During the first 24 hours after operation temperature increased to a maximum of $38.2^{\circ} \mathrm{C}$, and no special care was required. CPK was 59 units six hours after operation, 105 units after 24 hours, 17 units at four days, and 8 units at seven days.

\section{Discussion}

Although malignant hyperthermia is one of the most troublesome complications met by anaesthetists, the cause of this disease is not yet known and methods of prevention are imperfectly established at the present time. The inheritance of this trait and its relationship with other clinical or sub-clinical myopathy has recently been extensively discussed. Meanwhile, the prevention of malignant hyperthermia by identification of susceptible individuals by measurement of $\mathrm{CPK}^{21-23}$ muscle biops $y^{1.24}$ and other types of investigation are recommended.

The two cases which were reported here are dissimilar in the sense that the first patient represents a susceptible individual belonging to a family with subclinical myopathy identified by serum enzyme and electromyography examinations. The possibility of autosomal inheritance is strongly indicated. In addition, in this case, abnormal muscle contraction relaxation mechanism at the cellular level was also indicated. ${ }^{18,20}$ In the second case, the patient with arthrogryposis multiplex congenita, a myogenic pattern was identified by electromyographic studies, ${ }^{19}$ but no abnormality was demonstrated in members of the family.

A number of anaesthetics are said to act as triggering agents for malignant hyperthermia. It is therefore very difficult for the anaesthetist to select an appropriate anaesthetic for a patient known to be susceptible to this syndrome either through previous reaction or family history. Although nitrous oxide, ketamine, neuroleptanalgesia, and barbiturates are said to be drugs which do not act as triggering agents, ${ }^{25}$ they are not completely safe. For example, ketamine anaesthesia had been used previously in our first patient when a rise of temperature was observed during the operation, although in that case the malignant hyperthermia was controlled by cooling at an early stage. It is also reported that malignant hyperthermia has been triggered by ketamine. ${ }^{12}$ One of the side effects of ketamine anaesthesia is a rise in temperature, so that the statement that ketamine does not act as a triggering agent must be questioned. Relton ${ }^{25}$ successfully used meperidine with nitrous oxide and oxygen in patients with Malignant Hyperthermia and reports success with this method. From his experience he recommended neuro- 
leptanalgesia. However, this is not entirely safe as it frequently requires the use of a muscle relaxant, and the use of muscle relaxants is one of those problems yet to be solved.

Hall, et $a l . .^{10}$ reports on thiopentone as a preventive against the onset of high temperature in swine. Honda, et al. used 2, 4-DNP to produce experimental high temperature in $\operatorname{dogs}{ }^{26}$ and as inducers used pentobarbitone, thiamylal and propanidid. The high temperatures caused by 2, 4-DNP was compared with that caused by those three drugs and it was found that high temperatures were produced more easily and at faster rates of rise in the propanidid group than with pentobarbitone and thiamylal. Such high fevers produced experimentally cannot be equated completely with malignant hyperthermia, but these results indicate that barbiturates do not act as triggering agents.

Hall, et al. ${ }^{10}$ reported that in his experiments Althesin prevented onset of hyperthermia in swine, while Harrison, ${ }^{11}$ in similar experiments, reported that hyperthermia caused by halothane can be prevented by a dose of Althesin; however, after onset or when halothane is used in conjunction with succinylcholine, it is reported to be ineffective. Page, et al. ${ }^{12}$ and Judelman, et al. ${ }^{13}$ reported that they had favourable results with the administration of Althesin to malignant hyperthermia susceptible patients. In this report the authors administered Althesin to two patients who had a past history of malignant hyperthermia with familial subclinical myopathy and to patients having arthrogryposis multiplex congenita who had fever under anaesthesia twice in the past. Althesin was used first with nitrous oxide and oxygen, and then twice in combination with nitrous oxide-oxygen and halothane. In no case was there abnormal rise of temperature or abnormal increase of CPK during or after operation, and no other complications were encountered. These reports endorse the special merit of using Althesin together with halothane suggested by the experiments carried out by Hall, et al. and Harrison. Thus Althesin can be regarded as an effective anaesthetic agent for patients who are sensitive to malignant hyperthermia. However, the mechanism by which Althesin prevents malignant hyperthermia is not clarified. Ellis, et al. reported a dramatic cure of malignant hyperthermia using dexamethasone" and since Althesin and dexamethasone are both steroids, the mechanism of the effective action is assumed to be somewhat related.

Regional anaesthesia (local, nerve block, spinal and epidural anaesthesia) should probably be used for malignant hyperthermia sensitive patients. However, when general anaesthesia is required it is thought appropriate to use Althesin with nitrous oxide and oxygen for short operations and Althesin combined with nitrous oxide-oxygen and other anaesthetics (including halothane) for operations of longer duration.

\section{SUMMARY}

General anaesthesia with Althesin was administered on two occasions to a patient who was identified as susceptible to malignant hyperthermia, in whom there was identified familial subclinical myopathy and once in another patient suffering from arthrogryposis multiplex congenita with a history of fever associated with two previous anaesthetics. In the first patient halothane was administered by 
accident in association with the Althesin, but no hyperpyrexia occurred. In the second instance nitrous oxide-oxygen and halothane were associated purposely with Althesin. In none of these cases was there any rise in temperature, muscle rigor or elevation of the serum CPK level. This experience corroborates the experimental evidence of Hall, et al. ${ }^{10}$ and Harrison, ${ }^{11}$ who reported that Althesin prevented the onset of hyperthermia, and the clinical reports of Page ${ }^{12}$ and Judelman. ${ }^{13}$ Althesin can be assumed to be an effective anaesthetic for malignant hyperthermia susceptible patients.

\section{RÉSUMÉ}

L'Althésin a été utilisé à deux reprises lors d'interventions ophtalmologiques chez un enfant ayant présenté antérieurement un épisode d'hyperthermie maligne. A la suite de cet épisode, une étude familiale électromyographique avait démontré une susceptibilité à la maladie. Lors de la seconde anesthésie à l'Althésin, de l'Halothane a été ajoutée accidentellement au protoxyde d'azote utilisé en maintien.

Chez un second enfant, avec une histoire de température lors de deux anesthésies antérieures, l'Althésin a également été utilisé avec du protoxyde d'azote et, cette fois-ci, on a ajouté volontairement de l'Halothane au protoxyde.

Dans tous les cas, nous n'avons observé aucune élévation de température, aucune rigidité musculaire et aucune modification des CPK.

Ceci confirme les énoncés de Hall et coll., ainsi que ceux de Harrison, à savoir l'Althésin prévient l'hyperthermie et vient s'ajouter aux rapports cliniques de Page et Judelman sur la sécurité de cet agent pour les malades avec une susceptibilité connue à l'hyperthermie maligne.

\section{REFERENCES}

1. Ellis, F.R., Keaney, N.P., Harriman, D.G.F., Sumner, D.W., Kyai-Mensh, K., Pyhrel, J.H., Harcreaves, J.B., Parikh, R.K., \& Mulrooney, P.L. Screening for malignant hyperpyrexia. Brit. Med. J. 3: 559 (1972).

2. Brit, B.A. Recent advances in malignant hyperthermia. Anesth. \& Analg. $51: 841$ (1972).

3. Moulds, R.F.W. \& Denborough, M.A. Biochemical bases of malignant hyperpyrexia. Brit. Med. J. 2: 241 ( 1974 ).

4. KATz, D. Recurrent malignant hyperpyrexia during anesthesia. Anesth. \& Analg. 49: 225 (1970).

5. Harrison, G.G. Anaesthetic-induced malignant hyperpyrexia: a suggested method of treatment. Brit. Med. J. 3; 454 (1971).

6. Leigh, M.D., Lewis, G.B., Scott, E.B., \& Herbert, W. Successful treatment of malignant hyperthermia. Anesth. \& Analg. 50:39 (1971).

7. NoBle, W.H., MCKEE, D., \& GATEs, B. Malignant hyperthermia with rigidity successfully treated with procaine amide. Anesthesiology $39: 450$ (1973).

8. Brebner, J. \& Jozefowicz, J.A. Procaine amide therapy of malignant hyperthermia: a case report. Canad. Anaesth. Soc. J. 21: 96 (1974).

9. Ellis, F.R., Clarke, I.M.C., Appleyard, T.N., \& Dinsdale, R.C.W. Malignant hyperpyrexia induced by nitrous oxide and treated with dexamethasone. Brit. Med. J. 4: 270 (1974).

10. Hall, L.W., Trim, C.M., \& Woolf, N. Further studies of procaine malignant hyperthermia. Brit. Med. J. 2: 145 (1972).

11. Harrison, G.G. Althesin and malignant hyperpyrexia. Brit. J. Anaesth. 45: 1019 (1973).

12. Page, P., Morcan, M., \& LoH, L. Ketamine anaesthesia in paediatric procedures. Acta Anaesth. Scand. 16:155 (1972). 
13. Judelman, H. \& Pirie, D.H. Anaesthesia in a patient with previous malignant hyperpyrexia. Brit. J. Anaesth. 46: 519 (1974).

14. Campbell, D., Forrester, A.C., \& Miller, D.C. A preliminary clinical study of CT-1341 a steroid anaesthetic agent. Brit. J. Anaesth. 43: 14 (1971).

15. Toyooka, H., Wakushima, Y., Matsuda, D., et al. Clinical experience of a new steroid anesthetic (CT-1341). Jap. J. Anesth. 21 (11): 1141 (1972).

16. Takahashi, T., Namiki, A., OGAwa, H., et al. Clinical studies on new steroid anesthetic CT-1341 (Althesin-Glaxo), Part 1. Jap. J. Anesth. 21 (12): 1232 (1972).

17. Takahashi, T., Ogawa, H., Takahashi, M., et al. Clinical studies on new steroid anesthetic CT-1341 (Althesin-Glaxo). Jap. J. Anesth. 22(5): 364 (1973).

18. Konno, K., Yamashiro, H., Hagiwara, M., et al. Biochemical and electromyographic study on a family of malignant hyperpyrexia. Jap. J. Anesth. 23(9): 854 (1974).

19. IтонDA, Y., et al. Anesthesia for patients with arthrogryposis multiplex congenita. Jap. J. Anesth. 25 (7): 697 (1976).

20. KonNo, K, et al. Electromyographical and mechanomyographical studies on muscle in the family of malignant hyperpyrexia. Hiroshima J. Anesth. 12(1):31 (1976).

21. Denbonough, M.A., Ebeling, P., King, J.O. \& ZAPS, P. Myopathy and malignant hyperpyrexia. Lancet 2: 1138 (1970).

22. IsAaCs, H. \& BARLow, M.B. Malignant hyperpyrexia during anesthesia; possible association with subclinical myopathy. Brit. Med. J. 1: 275 (1970).

23. King, J.O., Denborovgh, M.A., \& ZAPS, P.W. Inheritance of malignant hyperpyrexia. Lancet 1: 365 (1972).

24. Moulds, R.E.F. \& Denborouch, M.A. Procaine in malignant hyperpyrexia. Brit. Med. J. 4: 526 (1972).

25. RELTON, J.E.S. Malignant hyperthermia-anesthetic techniques and agents: In International Symposium on Malignant Hyperthermia (eds. Gordon, R.A., Britt, B.A., and Kalow, W.) 425, Springfield: Charles C. Thomas (1973).

26. Honda, N., et al. Biochemical features on 2,4-dinitrophenol induced malignant hyperthermia in dogs. Jap. J. Anesth. 25(5): 527 ( 1976). 